\title{
DEVELOPING A LINEAR PROGRAMMING MODEL TO MAXIMIZE PROFIT WITH MINIMIZED LEAD TIME OF A COMPOSITE TEXTILE MILL
}

\author{
Sourav Kumar Ghosh ${ }^{1}$, Sumon Hossain ${ }^{2}$, Hafijur Rahman ${ }^{3}$, Naurin Zoha ${ }^{4}$ and Mohammad Arif-Ul \\ Islam $^{5}$
}

\author{
${ }^{1,2,3}$ Bangladesh University of Textiles (BUTEX). Dhaka-1208, Bangladesh. \\ ${ }^{4}$ Bangladesh University of Engineering and Technology (BUET). Dhaka-1000, Bangladesh. \\ ${ }^{5}$ Noakhali Science \& Technology University (NSTU). Noakhali-3802, Bangladesh.
}

Email: sourav@ butex.edu.bd, sumonbutexipe@gmail.com, hafijbutexipe@gmail.com, naurin.zoha@gmail.com, arif.rahad@gmail.com

Received: Apr $11^{\text {th }}, 2020$

Accepted: Apr $25^{\text {th }}, 2020$

Published: April 30th, 2020

Copyright (C2016 by authors and Galileo Institute of Technology and Education of the Amazon (ITEGAM).

This work is licensed under the Creative Commons Attribution International License (CC BY 4.0).

https://creativecommons.org/licen ses/by/4.0/

\section{(i) Open Acetes:}

\begin{abstract}
In the competitive market of apparel manufacturing, lead time for production plays a significant role in the delivery of the produces impacting the entire supply chain. Nowadays, composite manufacturers are leaning towards delivering within the shortest possible time to retain customers in this competitive market. To meet this challenge, proper production planning either using the correct method or the appropriate tools is a prerequisite condition; otherwise, mills will inevitably suffer losses or fail to drain out the maximum possible profit from the produces and may also suffer from promoting more expenses rather than yielding revenues. This study deals with the development of a linear programming model in order to reduce the complexity of the scheduling problem of a Composite Textile Industry in pursuit of maximizing profit or minimizing production costs. The model is developed considering process segmentation, utilization of machines and other resources, with respect to lead time. Four different components of the lead time are derived and an excel solver is used in solving the model.
\end{abstract}

Keywords: Production planning, Lead Time, Profit Maximization, Linear Programming, Composite Factory.

\section{INTRODUCTION}

Production planning and control (PPC) plays a vital role in the RMG (Ready-made Garments) manufacturing industry. More effort put on planning stages can ensure profit maximization through waste reduction, lead time reduction, maximum utilization of current resources. In textile industry, production planning may vary order wise. After receiving the order, the initial stage of the process begins which is the production planning that includes production scheduling, manpower allocation, machine utilization, etc. and planning the monitoring activities to ensure that proper control measures are in place and the desired product is achieved with respect to quantity, quality, delivery schedule, and cost of manufacturing to meet the customer requirements within the specified time frame. Most companies are not aware of the applications of PPC in other areas such as marketing and scheduling. The advantage of production planning is to create a system along with a set of standard procedures for the effective conversion of raw materials, labor, and other inputs into the final product (garment).

A composite factory is a factory where all the processes of a garment product are accumulated. For instance, a knitting factory has many processes involved with the product such as knitting, dyeing, washing, all-over print, yarn dyeing, embroidery \& sewing. Between these processes, we must follow several ladders which help us to attain the knitted garments to the customer with the ensuring quality. Bangladesh's export-oriented RMG sector is undergoing continual growth and it is currently showing huge potential to earn the highest amount of foreign currencies for the country. But as there are numerous numbers of competitors in this sector, the manufacturers are bound to control and lower down the lead time to produce the goods to live up to the competitive 
market. To meet all the demands of the product and deliver it within the lead time depends highly on the production planning. To reduce the lead time for various processes maintaining higher profit is challenging. We must consider all the constraints for it and a linear model is developed considering all these constraints to maximize profit through the optimization of lead time for different processes.

\section{LITERATURE REVIEW}

Shorter lead time leads to a more responsive supply chain that has a higher percentage of on-time deliveries and more satisfied customers and less cost of inventory [1]. For proposed a formula for product lead time which is vital for production planning. Product Lead-Time is the total time, which is required to Design, Plan, Control, and Process a given product through the Plant. This is the sum of Design Time, Manufacturing Planning Time, Manufacturing Control Time, and Manufacturing Lead Time [2]. A five-step procedure is presented to determine the lead time scheduling of operations of orders. It showed that the accuracy of the lead time scheduling is dependent upon the estimation of the order operating time accuracy [3]. A stochastic optimization algorithm based on the perturbation analysis technique is proposed to optimize the stage lead-times in a two-stage stochastic system [4]. By shortening the lead time, safety stock can be lowered hence it can reduce the loss caused by stock out [5]. Julie has investigated the relationship between price, lead time and delay [6]. Many engineering optimization problems can also be considered as linear programming problems where all or some of the parameters involved are linguistic in nature [7]. The application of linear programming models is resource allocation to activities problems, and analysis of a multi-plant production system to determine whether or not certain plants should be shut down as a result of the high cost of production [8]. For [9] developed a linear programming model on the textile industry with linear interactive optimizer software to determine the optimal numbers of each of three of its products to maximize the overall profit of the organization. Lindo software was used to solve a linear integer programming model of a food production problem to maximize the profit [10]. Represented a linear programming model to maximize profit [10]. Integer Linear Programming Model is used to select the supplier considering multiple criteria [11]. For [12] developed a linear programming model in optimal production planning for ICI Pakistan using linear programming. The techniques of linear programming which point to maximize the profit generated from the production patterns of the ICI Pakistan. The fuzzy environment was considered to rank the best choice using TOPSIS [13]. The Multimodal linear transportation model was solved using an excel solver to minimize the total transportation cost [14].

\section{METHODOLOGY}

In a composite factory, product lead-time is the sum of four components, which are Design Time, Manufacturing Planning Time, Manufacturing Control Time, and Manufacturing Lead Time.

Total Lead Time

$$
\mathrm{PLT}=\mathrm{TPD}+\mathrm{TMP}+\mathrm{TMC}+\mathrm{MLT}
$$

Where:

PLT $=$ Product Lead Time

TPD $=$ Product Design Time

TMP = Manufacturing Planning Time

$\mathrm{TMC}=$ Manufacturing Control Time
MLT = Manufacturing Lead Time

The Total Time of each phase is the amount of time in which, each function spends to complete its part of the job for a given product. This time largely depends on the kind of activities which each function needs to perform.

We mainly focus on Manufacturing Lead Time (MLT).

Table 1: Notation For an order of Q amount of knitting product.

\begin{tabular}{|c|c|c|}
\hline $\mathrm{P}_{\mathrm{O}}$ & $=$ & Product Price per piece \\
\hline MLT & $=$ & T Days \\
\hline $\mathrm{R}_{\mathrm{F}}$ & $=$ & The required amount of fabric \\
\hline$T_{1}$ & $=$ & The time required for knitting \\
\hline $\mathrm{C}_{\mathrm{K}}$ & $=$ & Knitting Capacity Kg/Day \\
\hline $\mathrm{P}_{\mathrm{K}}$ & $=$ & Knitting Price Per Kg \\
\hline $\mathrm{T}_{2}$ & $=$ & The time required for dyeing \\
\hline $\mathrm{C}_{\mathrm{D}}$ & $=$ & Dyeing capacity $\mathrm{Kg} / \mathrm{Day}$ \\
\hline $\mathrm{P}_{\mathrm{D}}$ & $=$ & Dyeing Price Per Kg \\
\hline $\mathrm{T}_{3}$ & $=$ & Time Required for Cutting \\
\hline $\mathrm{C}_{\mathrm{C}}$ & $=$ & Cutting Capacity Kg/Day \\
\hline $\mathrm{P}_{\mathrm{C}}$ & $=$ & Cutting Price Per Kg \\
\hline $\mathrm{T}_{4}$ & $=$ & The time required for printing \\
\hline $\mathrm{C}_{\mathrm{P}}$ & $=$ & printing capacity \\
\hline $\mathrm{P}_{\mathrm{K}}$ & $=$ & Printing Price Per Piece \\
\hline $\mathrm{T}_{5}$ & $=$ & The time required for sewing \\
\hline $\mathrm{C}_{\mathrm{S}}$ & $=$ & Sewing capacity \\
\hline $\mathrm{P}_{\mathrm{S}}$ & $=$ & Sewing Price piece \\
\hline $\mathrm{T}_{6}$ & $=$ & Time required for ironing $\&$ finishing \\
\hline $\mathrm{W}_{\mathrm{R}}$ & $=$ & Worker Rate \\
\hline $\mathrm{C}_{\mathrm{I} \& \mathrm{~F}}$ & $=$ & Ironing \& Finishing Capacity \\
\hline $\mathrm{P}_{\mathrm{I} \& \mathrm{~F}}$ & $=$ & Ironing \& Finishing Price Per Piece \\
\hline
\end{tabular}

Source: Authors, (2020).

Objective Function:

Max Profit: Z= Product Quantity* Product Price- Product Making Cost- Labor Cost

$\operatorname{Max} \mathrm{Z}=\mathrm{P}_{\mathrm{O}} * \mathrm{Q}-\left(\mathrm{P}_{\mathrm{K}} * \mathrm{R}_{\mathrm{F}}+\mathrm{P}_{\mathrm{D}} * \mathrm{R}_{\mathrm{F}}+\mathrm{P}_{\mathrm{C}} * \mathrm{R}_{\mathrm{F}}+\mathrm{P}_{\mathrm{P}} * \mathrm{Q}+\mathrm{P}_{\mathrm{S}} * \mathrm{Q}+\right.$ $\left.\mathrm{P}_{\mathrm{I} \& \mathrm{~F}} * \mathrm{Q}\right)-\left(\mathrm{T}_{1}+\mathrm{T}_{2}+\mathrm{T}_{3}+\mathrm{T}_{4}+\mathrm{T}_{5}+\mathrm{T}_{6}\right) * 24 * \mathrm{~W}_{\mathrm{R}}$

Subject To

$\mathrm{R}_{\mathrm{F}} \leq \mathrm{T}_{1} * \mathrm{C}_{\mathrm{K}}$

$\mathrm{R}_{\mathrm{F}} \leq \mathrm{T}_{2} * \mathrm{C}_{\mathrm{D}}$

$\mathrm{R}_{\mathrm{F}} \leq \mathrm{T}_{3} * \mathrm{C}_{\mathrm{C}}$

$\mathrm{Q} \leq \mathrm{T}_{4} * \mathrm{C}_{\mathrm{P}}$

$\mathrm{Q} \leq \mathrm{T}_{5} * \mathrm{C}_{\mathrm{S}}$

$\mathrm{Q} \leq \mathrm{T}_{6} * \mathrm{C}_{\mathrm{I} \& \mathrm{~F}}$

$\mathrm{T}_{1}+\mathrm{T}_{2}+\mathrm{T}_{3}+\mathrm{T}_{4}+\mathrm{T}_{5}+\mathrm{T}_{6} \leq \mathrm{T}$

$\mathrm{T}_{\mathrm{i}=1,2,3,4,5,6} \geq 0$

Table 2: Ordering Data.

\begin{tabular}{|l|l|}
\hline Order Quantity & Price per Unit (\$) \\
\hline 10000 & $\$ 3.00$ \\
\hline
\end{tabular}

Source: Authors, (2020).

Our product is knitted top. Garments components are front, back, and sleeves and the lead time is 60 Days. Fabric consumption for a knitted top can be calculated by using the following formula:

Consumption in grams $=\left\{\left(\mathrm{L}^{*} \mathrm{C}\right)+(\mathrm{B} * \mathrm{SL})\right\}$ $* 2 * \mathrm{GSM} / 10000$ grams (when length units are in centimeter). 
Where:

Table 3: Equation legend.

\begin{tabular}{|l|l|l|}
\hline C & $=$ & Chest +allowance \\
\hline L & $=$ & ength of the body measure + allowance \\
\hline SL & $=$ & Sleeve length +Allowance \\
\hline B & $=$ & Biceps +allowance \\
\hline GSM & $=$ & fabric weight in grams per square meter \\
\hline
\end{tabular}
Source: Authors, (2020).

Fabric consumption $(\mathrm{gm})=\{(\mathrm{L} * \mathrm{C})+(\mathrm{B} * \mathrm{SL})\} * 2 * \mathrm{GSM} / 10000 \mathrm{gm}$ $=[\{(33 * 25)+(10 * 2 * 27.5)\} * 2 *(2.54 * 2.54) * 200] / 10000$ grams (Note: 2.54 is inch to $\mathrm{cm}$ conversion factor)

$=[\{825+550\} * 400 * 6.45] / 10000$ grams

$=354.83$ grams

For 10000 pieces Required Fabric,

$\mathrm{R}_{\mathrm{F}}=345.83 * 10000=3458300$ grams

$=3458.3 \mathrm{Kgs} \approx 3459 \mathrm{Kgs}$

Table 4: Production Capacity.

\begin{tabular}{|l|l|}
\hline Required Fabric (Kg) & 3459 \\
\hline Knitting Capacity (Kg/Day) & 600 \\
\hline Dyeing Capacity (Kg/Day & 700 \\
\hline Printing Capacity & 2000 \\
\hline Cutting Capacity & 700 \\
\hline Sewing Capacity & 2000 \\
\hline Finishing Capacity & 2000 \\
\hline
\end{tabular}

Source: Authors, (2020).

Table 5: Process Pricing.

\begin{tabular}{|l|l|}
\hline Item & Cost \\
\hline Knitting Price Per Kg & $\$ 3.40$ \\
\hline Dyeing Price Per Kg & $\$ 1.50$ \\
\hline Cutting Price Per Kg & $\$ 0.15$ \\
\hline Printing Price Per Piece & $\$ 0.20$ \\
\hline Sewing Price piece & $\$ 0.30$ \\
\hline Ironing \& Finishing Price Per Piece & $\$ 0.20$ \\
\hline Labor Cost Per Hour & $\$ 0.50$ \\
\hline
\end{tabular}

Source: Authors, (2020).

Table 6: Product Measurements.

\begin{tabular}{|l|l|}
\hline \multicolumn{1}{|c|}{$\begin{array}{c}\text { Measurements without } \\
\text { allowances }(\mathbf{c m})\end{array}$} & \multicolumn{1}{c|}{$\begin{array}{c}\text { Measurement with } \\
\text { allowances }(\mathbf{c m})\end{array}$} \\
\hline Chest (C) $=23.25 "$ & $+1.75 "=25 "$ \\
\hline Body Length (L) $=30.5 "$ & $+2.50 "=33 "$ \\
\hline Sleeve Length (SL) $=26 "$ & $+1.50 "=27.5 "$ \\
\hline Bicep (B) $=9.2 "$ & $+0.80 "=10 "$ \\
\hline Fabric GSM =200 & \\
\hline
\end{tabular}

Source: Authors, (2020).

Table 7: Initial decision variables.

\begin{tabular}{|c|c|c|c|c|c|c|}
\hline Decision Variable & $\mathrm{T} 1$ & $\mathrm{~T} 2$ & $\mathrm{~T} 3$ & $\mathrm{~T} 4$ & $\mathrm{~T} 5$ & $\mathrm{~T} 6$ \\
\hline Initial & 0 & 0 & 0 & 0 & 0 & 0 \\
\hline
\end{tabular}

Source: Authors, (2020).
Table 8: Required constraints.

\begin{tabular}{|c|c|c|c|}
\hline Constraint & Output Amount & & Required Amount \\
\hline knitting & 0 & $\geq$ & 3459 \\
\hline dyeing & 0 & $\geq$ & 3459 \\
\hline cutting & 0 & $\geq$ & 3459 \\
\hline printing & 0 & $\geq$ & 10000 \\
\hline sewing & 0 & $\geq$ & 10000 \\
\hline finishing & 0 & $\geq$ & 10000 \\
\hline Total Time & 0 & $\geq$ & 60 \\
\hline
\end{tabular}

Source: Authors, (2020).

\section{RESULTS}

Table 9: Results of variables.

\begin{tabular}{|c|c|c|c|c|c|c|}
\hline $\begin{array}{c}\text { Decision } \\
\text { Variable }\end{array}$ & $\mathrm{T} 1$ & $\mathrm{~T} 2$ & $\mathrm{~T} 3$ & $\mathrm{~T} 4$ & $\mathrm{~T} 5$ & $\mathrm{~T} 6$ \\
\hline Initial & 5.765 & 4.94143 & 4.94143 & 5 & 5 & 5 \\
\hline
\end{tabular}

Source: Authors, (2020).

Table 10: Result of the necessary restrictions.

\begin{tabular}{|c|c|c|c|}
\hline Constraint & Output Amount & & Required Amount \\
\hline knitting & 3459 & $\geq$ & 3459 \\
\hline dyeing & 3459 & $\geq$ & 3459 \\
\hline cutting & 3459 & $\geq$ & 3459 \\
\hline printing & 10000 & $\geq$ & 10000 \\
\hline sewing & 10000 & $\geq$ & 10000 \\
\hline finishing & 10000 & $\geq$ & 10000 \\
\hline Total Time & 30.6478571 & $\geq$ & 60 \\
\hline
\end{tabular}

Source: Authors, (2020).

Table 11: Final solution.

\begin{tabular}{|l|l|}
\hline Labor cost & $\$ 367.77$ \\
\hline Profit & $\$ 5,164.28$ \\
\hline Product Making Cost & $\$ 24,467.95$ \\
\hline
\end{tabular}

Source: Authors, (2020).

We have used Microsoft excel solver to solve the problem. We can see that the maximum profit is found to be $\$ 5164$ (Omitting Fraction) and this maximum profit will be gained if the project is completed within 31 days (By rounding up).

\section{CONCLUSION}

Production planning plays a vital role in setting up the pricing policy of the company. The linear programming model is solved using excel. The results show that lead time can be reduced to 31 days from 60 days to maximize the profit. This method can undoubtedly increase the effectiveness of a manager's decisions ensuring the maximum utilization of current resources. It gives management the ability to choose the best production plan out of many alternatives available. This model can be helpful to reduce the scheduling problems in a composite textile mill.

Production planning techniques have much wider applications than have been discussed in this article. The production models can be solved with different textile mill structures. One possible improvement to the model can be the inclusion of manpower capacities and it can be solved by formulating mixed linear-integer programming models.

Much wider application of the model would be that for a very large size mill which has spinning and knitting plants at different locations. The problem then becomes that of determining yarn and fabric quantities to be produced at the various centers and 
the specification of a distribution plan and the optimized transportation routes from the spinning to the knitting centers.

\section{REFERENCES}

[1] Chopra, S., Meindl, P., \& Kalra, D. V. (2013). Supply chain management: strategy, planning, and operation (Vol. 232). Boston, MA: Pearson.

[2] Fahimnia, B., Luong, L. H. S., Motevallian, B., Marian, R. M., \& Esmaeil, M. M. (2006). Analyzing and formulation of product lead-time (Doctoral dissertation, World Academy of Science, Engineering and Technology (WASET).

[3] Kušar, J., Brezovar, A., Grum, J., \& Starbek, M. (2004). Realistic lead time scheduling of operations of orders. International Journal of Machine Tools and Manufacture, 44(10), 1037-1046.

[4] Feng, D. Z., Jiang, M. X., \& Chen, L. L. (2005, July). Leadtime planning in stochastic production system: An approach using perturbation analysis. In IEEE International Conference Mechatronics and Automation, 2005 (Vol. 3, pp. 1134-1138). IEEE.

[5] Senapati, A. K., Mishra, P. C., Routra, B. C., \& Biswas, A. (2012). An extensive literature review on lead time reduction in inventory control. International Journal of Engineering and Advanced Technology (IJEAT), 1(6).

[6] Wijaya, J. (2013). The relationship between price, lead time, and delay toward the order quantity in steel manufacturer. Universal Journal of Industrial and Business Management, 1(1), 17.

[7] Elamvazuthi, I., Ganesan, T., Vasant, P., \& Webb, J. F. (2010). Application of a fuzzy programming technique to production planning in the textile industry. arXiv preprint arXiv:1001.2277.

[8] Raichurkar, P., \& Ramachandran, M. (2015). Recent trends and developments in textile industry in India. International Journal on Textile Engineering \& Processes, 1(4), 47-50.

[9] Murugan, N., \& Manivel, S. (2009). Profit planning of an NGO run enterprise using linear programming approach. International Research Journal of Finance and Economics, 23, 443-454.

[10] Kriri, Q. M. (2018). Use of Linear Programming for Optimal Production in a Production Line in Saudi Food Co. International Journal of Industrial and Manufacturing Engineering, 12(3), 467471.

[11] Ghosh, S. K., Zoha, N., Chowdhury, T. Z., \& Ahmmed, M. S. (2018). Supplier Selection using Integer Linear Programming Model. Global Journal of Research In Engineering.

[12] Khan, I. U., Bajuri, N. H., \& Jadoon, I. A. (2011). Optimal production planning for ICI Pakistan using linear programming and sensitivity analysis. International Journal of business and social science, 2(23).

[13] Ghosh, S. K., Zoha, N., \& Sarwar, F. A Generic MCDM Model for Supplier Selection for Multiple Decision Makers Using Fuzzy TOPSIS.

[14] Ghosh, S. K., Rashid, M. M., \& Zoha, N. Development and Optimization of A Single Stage Multimodal Fixed-Cost Transportation Problem. 